\title{
An Investigation on the Forgotten Aspects of Cultures and Influence of Western Education among Communities in Niger State, Nigeria
}

\author{
Hannatu K. Ali, Mustapha Al-Yasa'U, Aminu A. Wushishi* \\ Department of History, College of Education, Minna, Niger State, Nigeria \\ Corresponding author: Aminu A. Wushishi, E-mail: amliyu@yahoo.com
}

\section{ARTICLE INFO}

Article history

Received: May 05, 2018

Accepted: June 25, 2018

Published: July 31, 2018

Volume: 6 Issue: 3

Conflicts of interest: None

Funding: TETFund

\begin{abstract}
In Niger State, there are more than fifteen different ethnic groups, each having its peculiar cultural affiliations, but the major ethnic groups in the State are; Nupe, Gbagyi, Fulani/Hausa. This paper tends to reflect on certain aspects of cultures which seem to have been forgotten among the three major ethnic groups, with focus on marriage most of whose aspects have been tempered by the influence of Western education. A qualitative method was used with the aim of extracting vital information from the participants regarding the forgotten aspects of cultures. Four aged people who are versed on culture were purposively selected. An in-depth interview, non-participatory observation and document analysis were used as means for data collection. All the participants were interviewed in English and each session of the interview lasted for about an hour to two hours. The interview was recorded, transcribed verbatim and analysed manually. Findings from the study discovered that; most of the beautiful and less expensive cultural practices in marriage have been forgotten, abandoned and changed with expensive and luxurious practices. The paper reviews the traditional marriage practices in the past among the Nupe, Gbagyi and the Fulani, and the influence of Western education on the forgotten aspects. The paper concludes by pointing out effects of the forgotten aspects on our contemporary society, particularly with the increase in population among the youths.
\end{abstract}

Key words: Culture, Marriage, Community, Western Education

\section{INTRODUCTION}

Cultural interactions no matter how limited it may be, bring conflict between the old and the new, when some aspects of the old are shed and some new features incorporated into the old. This development is because culture is dynamic and undergoes changes while retaining some aspect of itself. This has been the case in the culture of communities in Niger State. Some shed aspects of their culture are forgotten and only remembered in legends and stories faintly recounted by elders of the community. Some of the forgotten aspects of the culture are not only beautiful but relevant that need to be placed on record for revival and future generation usage. Bawa and Salahu (2012) indicated that good indigenous cultural aspects if maintained can positively promote cultural respects among various communities in Niger State.

The forgotten aspects of culture when documented will reveal the good and the bad ways of life as a people, and will help in improving where necessary. Besides, most of the forgotten aspects of the culture are hardly on record or documented. Therefore, writing about them will provide the opportunity to preserve them for future generations and will educate readers to appreciate the culture of other communities in Niger State, Nigeria.

\section{DEFINITION OF CULTURE}

Culture is a complex, all-embracing phenomenon. This complex nature of culture makes it difficult to have a single and acceptable definition. Consequently, there are many definitions of culture, a few of such definitions will be examined in this paper. One of the oldest and most widely accepted definitions of culture was by Taylor (1974, p. 27), who defined culture as '.. that complex whole which includes knowledge, beliefs, art, morals, customs and other capabilities acquired by man as a member of society'. This definition has attracted a lot of criticism by scholars. On the other hand, Adams (1972) defined culture as the integrated system of learned behavior patterns which are characteristics of the members of a society which are not the result of biological inheritance.

Bawa and Salahu (2012), described culture as the transmission of attitudes, values and norms from one generation to another. Considering the above definitions, culture can therefore be considered as what people learn from the society, which includes; mode of greeting, marriage, eating, interacting, attitudes, behavior and many other things that the society deem it fit for its members to learn. 


\section{OBJECTIVES}

This paper aims to reflect on certain aspects of cultures which seem to have been forgotten among the three major ethnic groups. More specifically, the paper will focus on marriage in the past among the three major ethnic groups in Niger State, which are; Nupe, Gbagyi and Fulani/Hausa and it will explore the influence of Western education on aspects of this culture.

\section{METHOD}

A qualitative method was used with the aim of extracting vital information from the participants regarding the forgotten aspects of cultures. Four aged people who are versed on culture were purposively selected. An in-depth interview, non-participatory observation and document analysis were used as means for data collection. All the participants were interviewed in English and each session of the interview lasted for about an hour to two hours. The interview was recorded, transcribed verbatim and analysed manually.

\section{RESULTS}

\section{Marriage among the Nupe}

The Nupe speaking peoples are located mainly around the Niger-Kaduna river confluence in Central Nigeria. History has revealed that the Nupe Kingdom was founded by Tsoede, a son of an Igala Prince and Nupe mother from Nku, a village near Bida (Eluwa, Ukagwu, Nwachukwu, \& Nwaubani, 2016). When his father died, he fled to Nupeko in Nupe land, where he made it his headquarters and began to launch attack on the neighbouring villages. He conquered so many areas and expanded his Kingdom which is now known as Nupe Land.

In the Nupe tradition the young boys and girls do not choose who to marry; it is the responsibility of their families to decide on their behalf and neither can decline the offer even if they do not know each other. When a boy's family ask for a girl's hand in marriage, an elderly family friend known as "rinna", or an intermediary, is sent to the girl's family to convey the intent and initiate the process. Based on the rinna's discussion with the girl's parent, the boy will be asked to go and meet the girl for an introduction. They will meet and briefly discuss under the supervision of an elderly woman in the family to make sure that things went on as expected. The boy will now notify his parent that he has officially met the girl and the marriage process will continue.

The next step is "Emikpe" official declaration of interest or engagement. The boy's family will now send certain items such as rice, kola nut, chickens and little amount of money. Of all the items the most essential is the kola nut and the little amount of money because it will be distributed to the girl's family members notifying them that the girl has gotten a boy who declared his interest to take her as wife. In some villages people will be invited to witness the engagement; when this is done, it is then illegal for any other family to seek for that girl's hand in marriage. Once this process has been completed the boy will continue to have link with other relatives in the girl's family by visiting them occasionally if they are not within the same village. He continues to extend gifts to the girl, her parents and her relatives. It is also part of tradition that the boy with permission of his parent from time to time assists the parent of his proposed wife in farming. This he does by extending the invitation to his friends and some members of his family to work on the in-laws' farm after all the necessary arrangement has been done through an intermediary. It is expected that at least he should do that once or twice before the marriage takes place. The girl's family will continue to exercise authority over the boy. They can at any time call on him for an assignment or send him on errand with no hesitation for him even if he is engaged with another commitment. Due to respect and shyness when he sits in his in-laws' house, he cannot say a word after greeting; he remains seated with his head bent down and cannot take his leave until he is granted permission by his in-laws. This process will continue until the two families decide on the date of marriage (Wasagi, 2018).

The boy's family through the intermediary will contact the girl's family on the proposed time for the marriage. The girl's family will on the other hand seek for time to deliberate on the issue with the intent of fixing the most appropriate time for the marriage. Consultations were made to get a convenient period for everyone to attend. If unanimously agreed, the boy's family will be notified, but in most cases the fixed date may sometimes exceed six months or a year, to enable both the families fully prepare for the ceremony. The girl's parent will demand for certain commodities to be used during the ceremony, such as; food, money, kola nut, goat, palm kernel or palm oil, firewood and so on. While all the preparations are going on, the time and date of the marriage will be kept out of the girl's knowledge as she may decide to run away. Few days to the marriage, an old woman holding a water in small-handy calabash will visit the bride's room early in the morning to knock at her door and call her name, once she answered and opened the door, the water will be poured on her body and the girl will start crying (Wasagi 2018).

After that, a day will be fixed when her friends will put "lalle" a plant-based dye on her body, a rigorous process as the bride will struggle very hard to prevent them from putting the "lalle" on her body, but at last the friends will over power her. The bride will be at this stage for about eight days, while some may spend between ten to twelve days as series of event may take place before she is conveyed to her groom's house in a spectacular mode known as "kpanganagi" a musical performance widely practiced by the Nupes for weddings and naming ceremonies. The colourful event that both families will participate in dancing, singing and jokes. In some families, Islamic preaching is observed all night before the wedding fatiha.

In the following morning, the groom's family will arrive with some requirements for the marriage, these will include; the dowry and cola nut which will be shared during the wedding fatiha. Late in the evening, the new bride is prepared for the journey to her husband's home, that night, the bride parents will hand her over to someone who serves 
as the intermediary between the two families. She will then be accompanied by her friends, her husband's friends and a few married women to her new home. In the new home, the groom's family received her into a newly prepared room. Then another round of celebration continued into the night, and may be repeated for about five to seven days. In the morning after the couple's wedding, the bride who is dressed in ceremonial attire goes back to her father's house to prepare a meal which she will takes back to her "eba yawo" (husband) house. They will seat on a mat and she will feed him in front of friends. After feeding her husband, the bride goes to her father's house again to make final preparation to leave for her new home, this time, married women gather in her father's compound to help her park the materials (cooking pots, utensils, mortar and a pestle) she will use in her husband's house.

\section{Marriage among the Gbagyi}

The Gbagyi are scattered all over the Central Nigeria predominantly around Kaduna, Nassarawa and Niger States. Their tradition of origin remained debatable as many Historians attributed their origins to Borno Empire, while some argued that the Gbagyi originated from Zazzau Emirate (Bawa 2014). Whatever the case maybe, the Gbagyi originated from the Northern Nigeria.

According to Gbagyi tradition, marriage is a thing of joy with so many rigourous processes. Initiation into marital status for a male "Gbagyiza" usually begins between fifteen to eighteen years of age, it is generally agreed that within this age limit the male reaches the puberty and capable of producing an offspring. In the case of female Gbagyi, it is expected that she should be between the ages of eight and ten at the beginning of the marriage process with assumption that before the wedding day she might have reached the age of twelve or thirteen.

In the Gbagyi culture, it is the responsibility of the boy to scout for a wife and when found, he discloses to his parents, who will then contact the family of the girl. Certain important questions are raised to determine if the girl's family are responsible or not. The likely questions are: Are they troublesome in the community? Is the family hardworking and not associated with laziness? What are the marriage records of the family particularly in the areas of impotency or infertility? Has anyone previously seek her hand for marriage? After all these questions has been answered positively, the groom is given a permission by his family to continue the process of courtship. But if all the answers are negative the boy will be advised to change another girl (Kutachi 2018).

After fulfilling the above stage, the next process is the courtship which could last for about seven years or even more. There are two approaches to courtship in Gbagyi tradition, the first approach is in the interest of the parents of the groom who directs his mind to a particular girl or contact the family of the said girl on his behalf. This is associated with the desire of the groom's parent for their son to marry from a family based on reasons known to them which could be private.

The second approach which is the most common among Gbagyi people is to allow the groom to scout for a wife by himself and report back to his parent whenever he find a girl of his choice. His parents will now send a delegate to the girl's parent. The parents of the girl will now seek for time to confirm from her whether she has interest or not. Few days later, the parent of the boy will be contacted with the answer. If positive, the girl's parent will request for two sets of plates from the boy's family signifying acceptance of their proposal. Then an intermediary known as "migbiyi" will be appointed, he will serve as a link between the two families. On the other hand, if the answer turned negative the boy will be asked to look for another girl (Chimbiri 2018).

After offer and acceptance from the both parents, the next stage is payment of dowry. The groom will be required to work at the bride's parent farm for certain period, probably seven years or more. He will be engaged in several kinds of farm work which includes; making ridges for farming, making yam heaps and harvesting of farm produce. The groom is usually assisted by his friends who will at least accompany him to work on the farm for about two to three times in a year, this will be repeated for seven consecutive years or more (Shagunu 2018). In order to be certain that the groom is capable of feeding the bride he is asked to bring $50 \mathrm{~kg}$ of Guinea corn of his own harvest which is called "wyiga".

During the courtship period, the suitor will be allowed to visit his bride to be accompanied by his friend or brother, while the bride will come with her sisters to attend to him. The groom and bride will not be permitted to meet without an accompanying partner this is to avoid temptation between them. In gbagyi tradition, any girl who became pregnant outside the wedlock will be sent out of the village until after her birth, because they consider that as a great shame to her family and even the close community members.

At the beginning of the wedding, certain sacrifices will be offered to seek for the blessing of the gods upon the couple. Chickens or goats are offered during the sacrifice, after which the bride is released to the groom's family to be accompanied by her friends and maids. After the wedding day, the bride will be kept in a hut, an elderly woman will stand outside the hut and loudly pronounce several names for the bride to carefully choose, once she heard the name that suites her she will rush out of the hut and will be taken to bathroom where she will be inspected to ascertain her virginity. By the next morning, those friends and maids who accompanied the bride will go into the bush to fetch firewood and equally fetch water for elderly people in the village. After this, the festivity continues with singing, dancing competitions, wrestling matches and so on. This will continue for seven days, then all the accompanying friends and maid will return back to their village on the seventh day leaving behind one who is called "mula chekun" who will assist the bride with domestic work for a period of time before finally returning back home, and that will mark the beginning of matrimonial journey for the couple.

\section{Marriage among the Fulani}

The Fulani people are traditionally believed to have originated from the North Africa and Middle East to West Africa, they are among the most widely dispersed and cultur- 
ally diverse people in Africa. They move from one place to another, and can be found in so many places in Nigeria, but predominantly around the North-Eastern Nigeria. There are quite reasonable number of them in the North Central Nigeria, particularly around Kwara, Kogi and Niger States.

There are two groups of Fulani, the cattle and the town Fulani. Among the cattle Fulani, a young man was not expected to marry until he has passed a manhood test called "Sharo". Youth would assemble in a playground usually at the Chief palace or a designated place approved by the Chief. A circle will be formed and a young man will get into the middle of the circle and begin to praise himself "Kirari" while this is on, a challenger will now appear with a stick on his hand and stand in front of the young man, he then hit his chest with the stick, at times blood will appear, but generally there was a burning painful sensation. The victim, however must never portray any sign of pain rather scornfully spat on the ground. That is the "sharo" that signifies that the young man is now ready to marry (Dioka 1997).

The choice of a wife was a serious issue among the $\mathrm{Fu}-$ lani. Generally, the Fulani were and still are hardworking and a wife must possess certain attributes. She must be able to run the home completely and with diligence especially during the long absence of the husband. That is why the search for a wife is a rigorous one. The Fulani chooses a wife from a close relation and marry almost within the family circle. After the choice of the bride had been made, the bride price was negotiated for and paid in cattle, dresses and other items. The prospective husband must fill a number of boxes with dresses for the new bride. After these, the bride went to her husband's house. The final test of the marriage, as in all other communities in Niger State, was chastity before marriage, which was greatly treasured. On the first night of the marriage, white sheet was spread on the bed. If stained with blood, the bride and her family were highly respected. This implied that she remained a virgin before getting married. If she was not a virgin it will bring great shame to her family.

\section{Influence of Western Education}

Western education was first introduced in Nigeria by the Portuguese who visited Benin City in 1472 and established their trading ports (Fafunwa,1995). By 1515 the first school was established at the Oba of Benin's palace with the aim of educating the Oba's children and his king makers. This marks the beginning of influence on the cultural life of Nigerian communities. In September1842 Rev. Thomas Birch freeman assisted by William De Graft introduced Western Education in Badagry, Lagos, which later spread to different parts of Nigeria (Fafunwa, 1995).

Niger State, formally known as Niger Province occupied an enviable position in Nigeria due to her strategic location. The province was located in the central part of the country, the geographical significance of the province is reflected in the fact that Zungeru village in the province had served as the initial headquarters of the Colonial Government from 1901-1907 (Abdul-Majid 2010). Missionary Schools were established in the province particularly in Wushishi and Bida around 1906. This was in addition to a number of schools established by the Church Missionary Societies in places such as; Kateregi in 1904, Kuta in 1905, Mokwa and Kutigi in 1906. Prominent among the schools that were later established in the province were Bida Native Authority School and Kontagora Native Authority Schools for Sons of Chiefs and their relatives in 1912 (Abdul-Majid 2010).

With the establishment of these schools, ideas and western cultures was introduced in the school curriculum whereby indigenous Nigerian would learn about these ideas and cultures as against the local inherited cultural practices. The appearance of the western culture in schools greatly affected the cultural practices of communities in Niger State. The traditional ways of marriage among the three major ethnic groups in the state has changed. For instance, it is the responsibility of the family to choose or decide the kind of wife their child will marry; this has a great positive impact on marriage. Because in African tradition it is assumed that the elders or parents have more wisdom than the child, they can forecast what the child cannot see no matter how smart the child may be. So, they will have to scrutinize the family background of the girl before allowing their child to seek for her hand in marriage. With the influence of Western education this aspect has changed, a child now chooses who to marry, he arranges with the girl and then notify his parent on their decision, he does so with less emphasis on her family background. The items that are collected by the bride's family during introduction ceremony have outrageously increased compared to the earliest practices. Bride price is

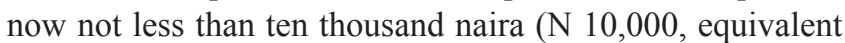
of \$30); the groom also must fill up a set of boxes with wrappers and underwear, one basket of kolanut and an additional two thousand naira as token. Western education has now made introduction ceremonies more elaborate than what was obtainable in the past as the couple do organize a dinner party with friends and well-wishers which will cost thousands of Naira. Unlike in the past where the time and date of the marriage was kept out of the girl's knowledge to prevent her from running away, with western education the time and date is now made known to the couple and invitation cards are also printed prior to the wedding date. "Kpanganagi", a musical performance widely used to accompany the bride to her groom's house, has now been changed; flashy and expensive cars are used instead. The joy of dancing, singing and jokes has been wiped away with the use of Western music. The additional days of celebration at the groom's house have been cancelled; the bride friends will only spend a night and leave the next day, the opportunity of relatives helping the groom to set-up her house is minimized.

Some aspect of Gbagyi's traditional marriage has also been forgotten with the influence of western education. The emphasis on early marriage starting at the age of fifteen to eighteen for the boys and eight to ten for the girl has been cancelled. A Gbagyi man can reach the age of thirty or more before thinking of marriage, while a Gbagyi woman can be more than twenty-five before marriage. Emphasis on some uncompromising questions such as; Is the family hardworking and not associated with laziness? What are the marriage records of the family particularly in the areas of impoten- 
cy or infertility? Has anyone previously seek her hand for marriage? After all these questions has been answered positively, the groom is given a permission by his family to continue the process of courtship.

The long courtship whereby the boy and the girl will understand each other better has been cancelled. At present, a Gbagyi boy can propose and marry a girl within one year. With western education, all the cheap sacrifices of chickens and goat is considered as old fashion and has been replaced by high cost and expensive sacrifices.

For the Fulani, the idea of chastity before marriage has been abandoned, many Fulani girls can be found flatting, having affairs with other men before marriage. Marrying within the clan has been cancelled, a Fulani girl can marry outside her clan and the same to Fulani boy. The popular festival "Sharo" whereby the youth will challenge each other before marriage is no longer in existence. All these aspects of cultures have been forgotten, replaced or abandoned as a result of the influence by the Western education.

\section{CONCLUSION AND RECOMMENDATIONS}

From the above discussion, it is clear that with the advent of western education many aspects of marriage among the communities in Niger State have been eroded and forgotten. Most of the forgotten aspect are cheap and less expensive. Considering the current economic hardship in the State and the Country in general and the kind of flamboyant changes in the process of marriage which is making it difficult for the able youth to go into, these changes need to be revisited and revived. Expensive marriage ceremonies need to be stopped and replaced with cheap process as practiced in the past. This will reduce the yarning of the society that there are at present many more unmarried girls than in the past. There is the need for government to introduce in the school curriculum certain subjects or courses that has to do with the forgotten aspect of cultures to educate the younger generations about culture and its importance.

\section{REFERENCES}

Abdul-Majid A. (2010) Educational Development in Niger State: History, Political Dynamics, and Challenges for Nation Building. In Talla N.S et al (Eds.). Education for Sustainable Development in Nigeria. Jos Nigeria: Smartprint pub.

Adams, E.H. (1972). Anthropology: The Study of a Man (4 ${ }^{\text {th }}$ Edition). McGraw Hill Inc, New York.

Bawa, M.M. \& Salahu M.L. (2012). A study on Nigeria People and Culture. Minna: Star Publishers.

Bawa, M.M. (2014). The Political Economy of Minna Emirate in the $20^{\text {th }}$ Century (Unpublished PhD thesis). Department of History, University of Abuja.

Fafunwa, A.B. (1995). History of Education in Nigeria. Ibadan: NPS Educational Publishers Ltd., Trust House.

Dioka, L.C, (1997). Forgotten Aspects of Nigerian Culture. Ibadan: Davidson Press.

Eluwa, U., Nwachukwu \& Nwaubani (2016). A History of Nigeria for Schools and Colleges.Onitsha: Africana First Publishers.

Interview with Alhaji Alhassan Wasagi, on the $6^{\text {th }}$ January 2018. A 70-year-old Nupe Man.

Interview with Alhaji Musa Kutachi, on the $13^{\text {th }}$ January 2018. A 76-year-old Nupe Man.

Interview with Shagun Mila, on the 27 $7^{\text {th }}$ of March 2018. A 78-year-old Gbagyi man.

Interview with Chimbiri Tako, on the 27 $7^{\text {th }}$ of April 2018. A 78-year-old Gbagyi man.

Taylor, E.B. (1974). Primitive Culture. Boston: Estate \& Lauviat Publishers. 